\title{
Unsaturated hydraulic conductivity of compacted bio- cemented lateritic soil in municipal solid waste containment application
}

\author{
Kolawole Juwonlo Osinubi ${ }^{1}$, Emmanuel Gadzama ${ }^{2}$, Adrian Oshioname Eberemu ${ }^{1 *}$ and Thomas Stephen Ijimdiya ${ }^{1}$. \\ ${ }^{1}$ Department of Civil Engineering, Ahmadu Bello University, Zaria, Nigeria \\ 1*Dept of Civil Engineering and African Centre of Excellence on New Pedagogies in Engineering Education Ahmadu Bello University \\ Zaria, Nigeria \\ ${ }^{2}$ Department of Civil Engineering, Modibbo Adama University of T ech nology, Yola, Nigeria
}

\begin{abstract}
Most engineering infrastructures, including municipal solid waste containment facilities, are situated in unsaturated zone. The use of chemical additives for soil improvement has been linked to the adverse environmental issues being experienced globally. Research into more sustainable methods of soil improvement has led to the discovery of a novel and innovative method known as microbial induced calcite precipitation (MICP). Lateritic soil was treated with stepped Sporosarcina pasteurii (S. pasteurii) suspension density up to $2.40 \times 10^{9}$ cells $/ \mathrm{ml}$ at moulding water content (MWC) $-2,0$ and $+2 \%$ relative to optimum moist ure content (OMC) before compaction using Reduced British Standard light (RBSL), British Standard light (BSL), West African Standard (WAS) or Intermediate and British Standard heavy (BSH) energies. Compacted specimens were saturated with cementation reagent in three cycles with $1 / 3^{\text {rd }}$ pore volume at 6 hours' interval to induce calcite precipitation at an ambient laboratory temperature of $24 \pm 2{ }^{\circ} \mathrm{C}$. The soil-water characteristics curves (SWCC) of the specimens were determined using pressure plate extractor over a pressure range of $10-1500 \mathrm{kPa}$. Unsaturated hydraulic conductivity values were predicted for the $\mathrm{S}$. pasteurii suspension densities considered using Brooks-Corey, van Genuchten as well as Fredlund and Xing curve fitting prediction models. Results show that the unsaturated hydraulic conductivity values of specimens prepared at lower, MWC relative to OMC were generally higher than at higher MWC regardless of compactive efforts and $S$. pasteurii suspension densities considered. The Brooks-Corey model gave the best predicted unsaturated hydraulic conductivity values which fit the requirements for waste containment facilities over the matric suction range and $S$. pasteurii suspension densities considered, than the van Genuchten and Fredlund Xing, when compared with measured values.
\end{abstract}

Keywords : Lateritic soil, Pore volume, Sporosarcina pasteurii. Suspension density, Unsaturated soils.

\section{Introduction}

Geotechnical engineering technology and practice as reported in the literature was developed in the temperate climate where the soils are mostly saturated. Therefore, it was much easier and fruitful to direct a substantial research interest towards problems involving saturated soils with positive pore-water pressure (Fredlund and Rahardjo, 1993b) [1]. The assumptions made in the design of liners and waste containment facilities is that throughout the lifespan of the facility, it will remain saturated. However, during the inactive (closure) stagethe soil is not totally saturated because most, if not all, engineering facilities are located within the unsaturated zones (known as the vadose zone) of the soil.

The study of unsaturated soils is an essential tool for the analysis of soil behaviour because the soils used in engineering construction are unsaturated (Fredlund and Rahardjo, 1993a) [2]. Although unsaturated soil has received much attention of researchers in the field of geotechnical engineering, the use or application of unsaturated soil mechanics is not only inexhaustible but still lags behind up-to-date knowledge (Chin et al., 2010) [3]. According to Tao et al. (2017) [4], more than $60 \%$ of the countries of the world are suffering the engineering harmbrought about by unsaturated soils, as such thestudy of unsaturated soil behavior targeted for engineering use is not only of theoretically significance but also of practical importance. In the studies of uns aturated soil, much emphas is was placed on the flow of water in the soil, however, the constitutive equations developed which have become generally accepted in geotechnical engineering consist of the following : volume change, shear strength, as well as flow in the unsaturated soil (Fredlund and Rahardjo, 1993a) [2]. Some of the key difficulties that exist in the meas urement of the properties of unsaturated soils include unsaturated soil laboratory tests being time-consuming and expensive, problems linked with the measurement of negative pore-water pressure in situ in unsaturated soil, the training of technical personnel to handle the test, etc. (Phoon et al., 2008 ; 2010 [5-6] ; Mahmood and Kareem, 2010 [7] and Wang et al. 2015) [8].

The use of chemical additives as a conventional method of soil improvement has been a common practice for over a century. However, the use of these chemicals, except sodiumsilicate, has been questioned becauseof the negative environmental issues associated with them Research into more sustainable methods of soil improvement has brought about the discovery of a new technique called Microbial Induced Calcite Precipitation (MICP). The aim of this study was the enhancementof the engineering properties of a deficient lateritic soil to be used in waste containment facilities using MICP approach. The targeted objectives include the

\footnotetext{
* Corresponding author: aeberemu@yahoo.com
} 
determination of the soil - water characteristic curves (SWCCs) of lateritic soil treated with different $S$. pasteurii suspension densities, moulding water content and compactive efforts. Also, Brooks -Corey (1964) [9], van Genuchten (1980) [10] and Fredlund and Xing (1994) [11] curve fitting models were us ed to predict volumetric water content and unsaturated hydraulic conductivity of the treated soil in relation to the measured laboratory values.

\subsection{Soil-Water Characteristics Curve}

Soil-water characteris tics curve (SWCC) was originally developed in the agriculture science. It is a plot that is used for the determination of the soil to store water at varied suction pressures (Mahmood and Kareem, 2010) [7]. Osinubiand Amadi(2010) [12], reported that SWCC is a plot that demonstrate the ability of soil to hold or release water when subjected to varying suction pressure. It also represents the association existing between soil water content at different suction pressure (Elkady et al., 2017) [13]. SWCC has played an importantrole in the use of unsaturated soil mechanics in geotechnical engineering practice ; Zapata et al., (2000) [14]. The curve is one of the earliest indirect methods used in the study of unsaturated soil that has shown some level of success because it is possible to approximate most unsaturated soil properties from saturated soil parameters and the SWCC (Fredlund and Rahadjo, 1993b; Chin et al., 2010; Braudeau et al. 2014 ; Rahimi et al. 2015; Alsherif et al. 2015 and $\mathrm{Li}$ et al. 2017) $[1 ; 3 ; 15 ; 16 ; 17$ and 18]. A SWCC is a bas is to regulate other important properties of soil such as unsaturated permeability and shear strength (Tao et al. 2017; Fredlund and Xing, 1994; Vanapalli et al., 1996 and Bo and Yulong, 2016). [4 ;11 ;19 and 20]. Fredlund and Rahardjo(1993a)[1] reported that fine grain soils have greater air entry pressure $\left(\psi_{a}\right)$, while those with broader collection of pore sizes (well graded) display more variations in matric suction with water content. For over five decades, several empirical equations were proposed to model SWCC with many of them having common and inters ecting parameters.

\section{Materials and Methods}

\subsection{Materials}

\subsubsection{Soil :}

The lateritic soilused in this research was obtained from a site located in Abagana community of Anambra state, Nigeria (Latitude 6 $6^{\circ} 10^{\prime} 15^{\prime \prime} \mathrm{N}$ and Longitude 6 $6^{\circ} 58^{\prime} 10^{\prime \prime} \mathrm{E}$ ). The method used was the disturbed sampling at a depth range of $0.5 \mathrm{~m}$ and $3.0 \mathrm{~m}$.

\subsubsection{Bacteria :}

The bacteria used in this research is Sporosarcina pasteurii, an organism frequently found in soil. It is Gram-positive, urease positive, spore-forming and rodshaped bacteria that was isolated and cultured from the soil sample.

\subsection{Methods}

\subsubsection{Bacteria culture/growth medium :}

The method used to identify the bacteria is the conventional method described by Cheesbrough (2006) [21]. Bacteria was cultured in an Ammonium-Yeast Extract media as delineated in Mortensen et al. (2011) and Feng et al. (2014) [22 and 23]. The organismwas isolated from soil and inoculated on media with this composition viz: (20 g yeast extract, $10 \mathrm{~g}$ ammonium chloride, $2 \mathrm{~g}$ urea and $0.1 \mathrm{~g}$ nickel in 1 litre distilled water) and $\mathrm{NaOH}$ was used to adjust the $\mathrm{pH}$ of the media to 9.0. The media was autoclaved at $121^{\circ} \mathrm{C}$ per $1.1 \mathrm{~kg}$ pressure for 15 minutes. 1 gram each of the soil samples were inoculated on each of the culture bottle and incubated at $37^{\circ} \mathrm{C}$ for $24-$ 48 hours to facilitate proper characterization i.e. is olation and identification.

\subsubsection{Bacteria cell density:}

The bacteria suspension was varied in stepped density of 0, 4.0, and 8.0 McFarland Standards, equal to $0 / \mathrm{ml}, 1.20$ x $10^{9} / \mathrm{ml}$ and $2.40 \times 10^{9}$ cells $/ \mathrm{ml}$. A maximum one-third $\left(1 / 3^{\text {rd }}\right)$ of the pore volume of organisms was mixed with the soil as recommended by Rows hanbakht et al. (2016) [24]. Pore volumes were determined for all the compactive efforts employed in the study.

\subsubsection{Sample preparation:}

$3000 \mathrm{~g}$ of the crumbled and air-dried soil sample sieved through BS No.4 sieve (4.76 mm opening) was mixed rigorously with $1 / 3^{\text {rd }}$ of its pore volume as the bacterial suspension density using moulding water contents in the range of $-2 \%$ and $+2 \%$ relative to optimum mois ture content. The treated soil s amples were cured for 12 hours in a securely closed plastic bags at $24 \pm 2{ }^{\circ} \mathrm{C}$ to facilitate better dis tribution and attachment of the bacteria onto the soil before compaction with the energy level considered. The compacted samples were flooded with the cementating reagent under gravity in three circles with $2 / 3^{\text {rd }}$ of their pore volumes cementation mixture the same as those used in Dejong et al. (2006) [25] to initiate the MICP process. A stainless steel pipe having an intemal raduis of $25 \mathrm{~mm}$ and effective height of $50 \mathrm{~mm}$ was used in coring the seventy-two (72) specimens from the compacted soil and wrapped with polyethene sheets 24 hours after the third cycle. The cored specimens were later saturated by capillary action in a water tank for 3 weeks. Full saturation was confirmed only when water was obs erved to have risen to the top of the treated samples.

\subsubsection{Application of pressure on the pressure plate extractor.}

The fully saturated specimen was placed on a porous stone that only permit the movement of water through the pore inside the chamber of the pressure plate extractor. Controlled air from a compressor was used to apply pressure of 10, 500 and $1500 \mathrm{kPa}$, respectively, on the specimens until water stopped dripping from an outlet on the pressure plate extractor. The application of pressure on the specimens was carried for about 10 weeks, the whole process froms ample preparation to the application 
of the pressure lasted for about 3 months. The equipment was dismantled after the test, while the specimens were placed in an oven to determine the final water content. The volumetric water content was calculated from the water contents for each pressure applied and the data was used to plot the soil - water characteristic curves (SWCCs).

\subsubsection{Model equations}

Alot of models for the prediction of SWCCs have been used (Chin et al., 2010 ; Miller et al., 2002) [3;26] however, an extensive review of the subject matter by Leong and Rahardjo (1997) [27] showed that the Brooks - Corey (1964), van Genuchten (1980) [9,10] as well as Fredlund and Xing (1994) [11], are frequently used by researchers. Therefore, the three models expressed in equations (1) - (4) were considered in this study.

The Brooks - Corey Model[9] is expressedas:

$$
\theta=\frac{\theta-\theta_{r}}{\theta_{s}-\theta_{r}}=\left(\frac{\psi_{a}}{\psi}\right)^{\lambda} \quad \text { when } \psi \geq \psi_{a}
$$

and

$$
\Theta=1 \text { and } \theta=\theta_{s} \quad \text { when } \psi<\psi_{a}
$$

Where: $\Theta=$ normalized dimensionless volumetric water content

$\left(\psi_{a}\right)=$ Air Entry Suction or Bubbling Pressure

$\psi=$ suctionpoint

$\boldsymbol{\lambda}=$ the pore-size distribution index (Corey, 1994)[28];

which is related to the distribution of pores in the soil sample and can be deduced from the slope of SWCC van Genuchten (1980) model [10] is expressedas:

$$
\theta=\frac{\theta-\theta_{r}}{\theta_{s}-\theta_{r}}=\left\{\frac{1}{1+(p \psi)^{n}}\right\}^{m}
$$

Fredlund and Xing (1994) [11] model is expressedas:

$$
\theta=\frac{\theta-\theta_{r}}{\theta_{s}-\theta_{r}}=\frac{1}{\left\{\ln \left[e+\left(\frac{\psi}{a}\right)^{b}\right]\right\}^{c}}
$$

Where: $\boldsymbol{a}, \boldsymbol{b}, \boldsymbol{c}$ are the different soil fitting parameters described by Leong and Rahardjo (1997) [27] and $\boldsymbol{m}, \boldsymbol{n}$ and $\boldsymbol{p}$ are three soil fitting parameters described by van Genuchten (1980) [10] who also reported the relationship between $\mathbf{m}$ and $\mathbf{n}$ as:

$$
m=(1+1 / n)
$$

to attain a bounded form expression for hydraulic conductivity however that was found to decrease the flexibility of the model. Therefore, the parameters $\boldsymbol{m}$ and $\boldsymbol{n}$ should be used as obtained without using the relationship specified above to get precise predictive results. $\boldsymbol{p}$ is the turning point of the curve, which is ass ociated to the air-entry suction. $\boldsymbol{n}$ occurs at regulated volumetric water content of 0.5 , which controls the slope of SWCC about the pivot point such that as $\boldsymbol{n}$ increases the portion of the curve amid $\psi_{\mathrm{a}}$ and the knee (the point of inflexion) of SWCC becomes steeper(Miller et al., 2002) [26].

\subsubsection{Prediction of unsaturated hydraulic conductivity}

The calculation of unsaturated hydraulic conductivity using the models is linked to the measured saturated hydraulic conductivity with several parameters obtained from the SWCC. The prediction is es tablished on the following relations hip:

$$
k_{r}=k / k_{s a t}
$$

Where : $\mathrm{k}_{r}$ is a relative hydraulic conductivity; $\mathbf{k}$ is uns aturated hydraulic conductivity of the soil and $\mathbf{k}_{\text {sat }}$ is the saturated hydraulic conductivity of the soil determined in the laboratory. From Brooks-Corey (1964) model, [9] $\mathrm{k}_{r}$ in relation to the SWCC parameters is given as:

$$
K_{r}=\left\{\begin{array}{cc}
1 & ; \psi \leq \psi_{a} \\
\left(\frac{\psi_{a}}{\psi}\right)^{2+a \lambda} & ; \psi_{a}>\psi
\end{array}\right.
$$

From the van Genuchten(1980) model, [10] $\mathrm{k}_{r}$ in relation to the SWCC fitting parameters is given as:

$$
k_{r}=\frac{\left\{1-(\alpha \psi)^{n-1}\left[1+(\alpha \psi)^{n}\right]^{-m}\right\}^{2}}{\left[1+(p \psi)^{n}\right]^{m / 2}}
$$

Where $\boldsymbol{m}, \boldsymbol{n}$ and $\boldsymbol{p}$ are as described in SWCC.

Also, from Fredlund and Xing (1994) model, [11] $\mathrm{k}_{r}$ in relation to the $\mathrm{SWCC}$ fitting parameters is given as:

$$
K_{r}=\frac{1}{\left\{\ln \left[e+\left(\frac{\psi}{a}\right)^{b}\right]\right\}^{c}}
$$

Where: $\psi=$ suction point; $\boldsymbol{a}, \boldsymbol{b}$ and $\boldsymbol{c}$ are three different soil fitting parameters described by Leong and Rahardjo (1997) [27].

\section{RESULTS AND DISCUSSION}

\subsection{Unsaturated hydraulic conductivity}

\subsubsection{Effect of moulding water content relative to optimum :}

The changes recorded in the unsaturated hydraulic conductivity with moulding water content relative to optimum at matric suctions of 10,500 and $1,500 \mathrm{kPa}$ for Brooks-Corey (BC), van Genuchten (VG) and FredlundXing (FX) models is shown in Figs. 1a-c. Generally, unsaturated hydraulic conductivity predicted, reduced with increas ing moulding water content irrespectiveof the compactive effort and $S$. pasteurii suspension density used. It was observed that at $10 \mathrm{kPa}$ suction, the [9] Brooks - Corey model recorded higher predicted unsaturated hydraulic conductivity; which ranged between $4.70 \times 10^{-6} \mathrm{~m} / \mathrm{s}$ at 0 cells $/ \mathrm{ml}$ treated at $-2 \%$ dry of OMC to $9.75 \times 10^{-9} \mathrm{~m} / \mathrm{s}$ at $2.40 \times 10^{9}$ cells $/ \mathrm{ml}$ treated at $2 \%$ wet of OMC. [10] van Genuchten model recorded values in the range of $9.12 \times 10^{-12} \mathrm{~m} / \mathrm{s}$ at $2.40 \times 10^{9}$ cells $/ \mathrm{ml}$ treated at $\mathrm{OMC}$ to $7.35 \times 10^{-8} \mathrm{~m} / \mathrm{s}$ at 0 cells $/ \mathrm{ml}$ also treated at 
OMC. Furhtermore, [11] Fredlund-Xing models recorded values that ranged between $1.16 \times 10^{-8} \mathrm{~m} / \mathrm{s}$ at $-2 \%$ dry of OMC and $1.97 \times 10^{-9} \mathrm{~m} / \mathrm{s}$ at $+2 \%$ wet of OMC for 0 cells $/ \mathrm{ml}$ treated at $\mathrm{OMC}$, lower values ranging between $3.92 \times 10^{-9} \mathrm{~m} / \mathrm{s}$ and $4.33 \times 10^{-10} \mathrm{~m} / \mathrm{s}$ were recorded at 1.20 $\mathrm{x} 10^{9}$ cells $/ \mathrm{ml}$. Furthermore, at $10 \mathrm{kPa}$ suction pressure, the compacted treated soil was still saturated and did not exhibit uns aturated behaviour; when the suction pressure was increased to $500 \mathrm{kPa}$, the unsaturated behaviour increased. The Brooks - Corey [9] model recorded the lowest predicted unsaturated hydraulic conductivity in the range of $4.07 \times 10^{-16} \mathrm{~m} / \mathrm{s}$ at $2.40 \times 10^{9}$ cells $/ \mathrm{ml}$ treated at +2 $\%$ wet of OMC to $4.66 \times 10^{-9} \mathrm{~m} / \mathrm{s}$ at 0.0 cells $/ \mathrm{ml}$ treated at $+2 \%$ wet of OMC. The next lower prediction was recorded by [10] van Genuchten model in the range of $2.67 \times 10^{-11} \mathrm{~m} / \mathrm{s}$ at $2.40 \times 10^{9}$ cells $/ \mathrm{ml}$ treated at OMC to $4.66 \times 10^{-4} \mathrm{~m} / \mathrm{s}$ at 0.0 cells $/ \mathrm{ml}$ treated at OMC. Similarly, the Fredlund-Xing [11] model recorded relatively higher values which ranged between $1.15 \times 10^{-8} \mathrm{~m} / \mathrm{s}$ for 0 cells $/ \mathrm{ml}$ at $-2 \%$ dry of OMC and $4.18 \times 10^{-10} \mathrm{~m} / \mathrm{s}$ for $2.40 \times 10^{9}$ cells $/ \mathrm{ml}$ treated at $+2 \%$ wet of OMC. As the suction was increased to $1500 \mathrm{kPa}$, Brooks - Corey [9] model recorded similar but much lower results compared to those recorded at $500 \mathrm{kPa}$, in the range of $3.44 \times 10^{-18} \mathrm{~m} / \mathrm{s}$ at $2.40 \times 10^{9}$ cells $/ \mathrm{ml}$ treated at $+2 \%$ wet of $\mathrm{OMC}$ to $2.12 \times 10^{-7} \mathrm{~m} / \mathrm{s}$ at $1.20 \times 10^{9}$ cells $/ \mathrm{ml}$ treated at $-2 \%$ dry of OMC. Similarly, van Genuchten [10] model recorded predited values in the range of $1.42 \times 10^{-11} \mathrm{~m} / \mathrm{s}$ at $2.40 \times 10^{9}$ cells $/ \mathrm{ml}$ compacted at OMC to $5.07 \times 10^{-3} \mathrm{~m} / \mathrm{s}$ at 0 cells $/ \mathrm{ml}$
Compacted at OMC. At the same suction pressure, the Fredlund-Xing [11] model recorded relatively higher values which ranged from $4.05 \times 10^{-10} \mathrm{~m} / \mathrm{s}$ at $1.20 \times 10^{9}$ cells $/ \mathrm{ml}$ compacted at $+2 \%$ wet of OMC to $1.67 \times 10^{-8} \mathrm{~m} / \mathrm{s}$ at $2.40 \times 10^{9}$ cells $/ \mathrm{ml}$ compacted at $-2 \%$ dry of OMC. At matric suction pressures of $500 \mathrm{kPa}$ and $1,500 \mathrm{kPa}$, relatively the [10 and 11] model predictions were higher compared to the Brooks-Corey [9] model. From the results presented, all the models at varying suction pressure recorded unsaturated hydraulic conductivity lower than the maximum permisible value of $1.0 \times 10^{-9}$ $\mathrm{m} / \mathrm{s}$, however, the Brooks-Corey model [9] recorded much lower prediction of unsaturated hydraulic conductivity at higher suction pressure compared to the other two prediction models, this condition is commonly found in arid/s emi-arid regions like Nigeria. The results obtained of this study are similar to those reported by Os inubi and Eberemu, (2010); Osinubi and Bello, (2011) and Osinubi et al. (2015) [29-31] for soils treated with using different additives.

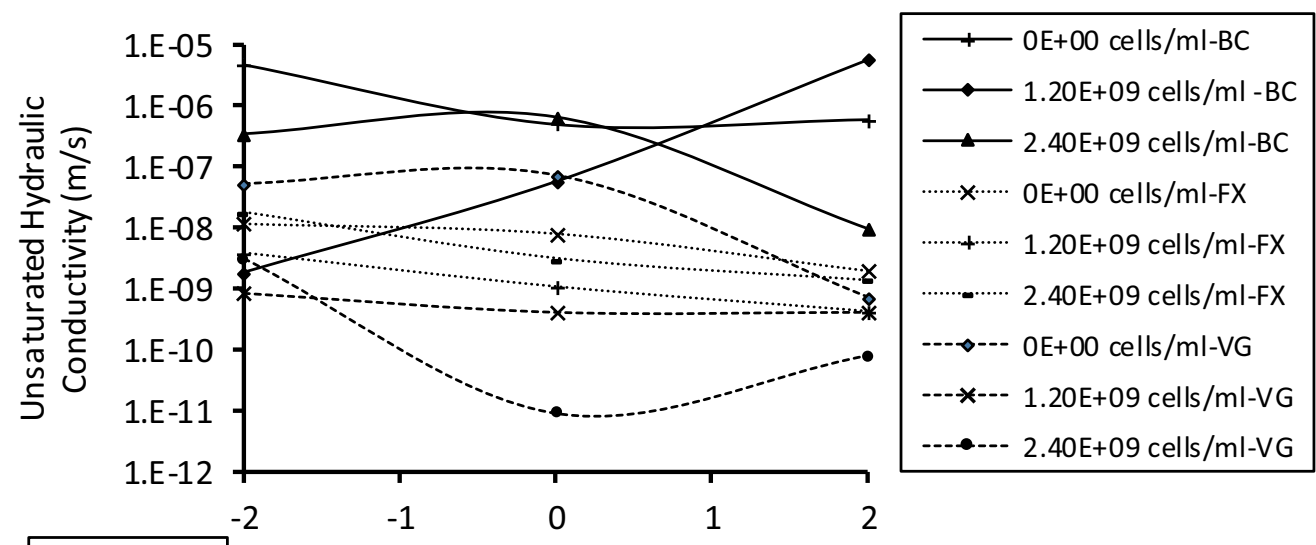

(A) 10kPa) Water Content Relative to Optimum (\%)

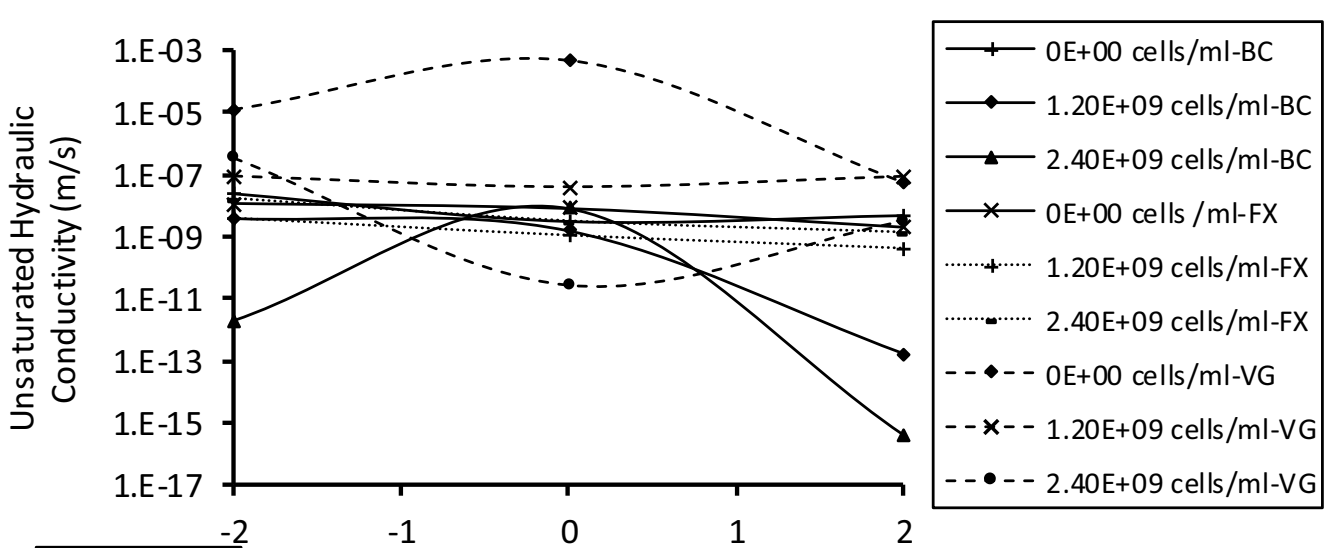

(B) 500kPa Water Content Relative to Optimum (\%) 


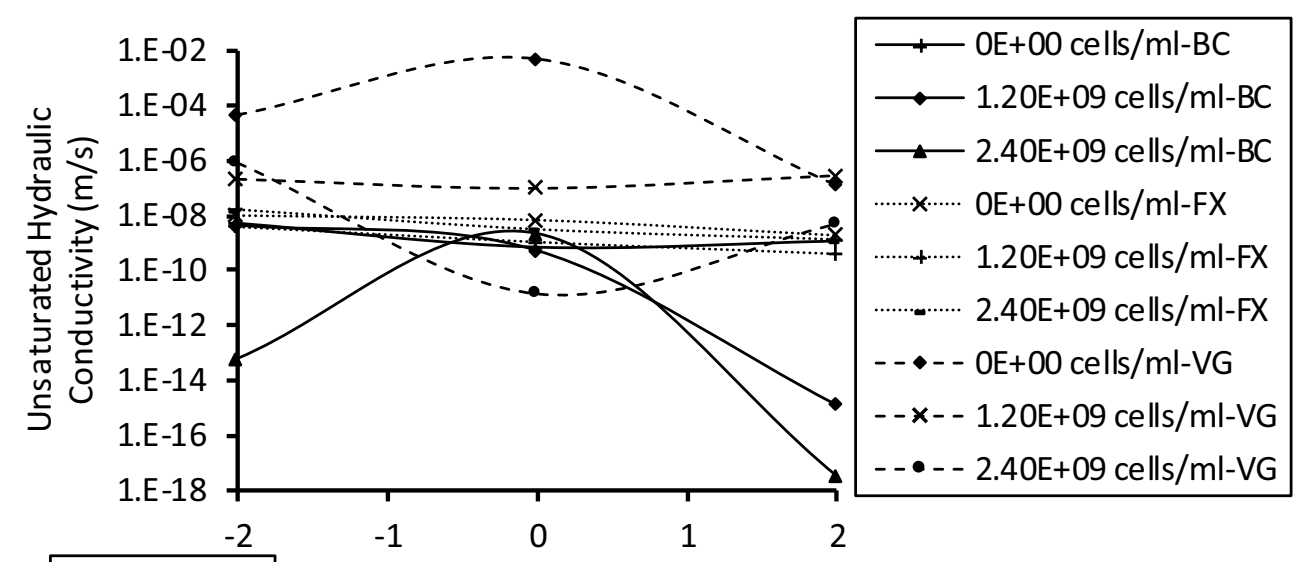

(C) $1500 \mathrm{kPa}$ Water Content Relative to Optimum (\%)

Fig.1 Variation of unsaturated hydraulic conductivity for lateritic soil compacted at optimum moisture content with water content relative to optimumbased on Brooks-Corey (BC), Fredlund-Xing (FX) and van Genuchten(VG) models at varying S. pasteurii suspension density for matric suction:(A) $10 \mathrm{kPa}$ (B) $500 \mathrm{kPa}$ (C) $1500 \mathrm{kPa}$

\subsubsection{Effect of Sporosarcina pasteurii suspension density}

The effect of $S$. pasteurii suspension density on the unsaturated hydraulic conductivity of specimens treated at OMC and compacted with RBSL, BSL, WAS and BSH energy is presented in Figs.2a-c. At lower matric suction (i.e., $10 \mathrm{kPa}$ ) when the soil was still in its saturated state; Brooks-Corey (1964) [9] model recorded higher predicted values than the other two models. The range of values were between $2.37 \times 10^{-8} \mathrm{~m} / \mathrm{s}$ at 0 cells $/ \mathrm{ml}$ to $1.80 \times 10^{-4} \mathrm{~m} / \mathrm{s}$ at $2.40 \times 10^{9}$ cells $/ \mathrm{ml}$. These predicted values did not satisfy the maximum permis sible regulatory value of 1.0 X $10^{-9} \mathrm{~m} / \mathrm{s}$. The van Genuchten (1980) [10] model recorded values in the range of $9.12 \times 10^{-12} \mathrm{~m} / \mathrm{s}$ at $2.40 \times 10^{9}$ cells $/ \mathrm{ml}$ to $3.52 \times 10^{-6} \mathrm{~m} / \mathrm{s}$ at 0.0 cells $/ \mathrm{ml}$, there was a general decrease in the predicted hydraulic conductivity values with increase in $S$. pasteurii suspension density. The Fredlund-Xing (1994) [11] model on the other hand recorded values in between [9 and 11] models, the predicted hydraulic conductivity values s lightly decreased with increase in $S$. pasteurii suspension density. At 500 $\mathrm{kPa}$ matric suction the van Genuchten [10] model showed higher predicted
Unsaturated hydraulic conductivity values in the range of $2.77 \mathrm{~m} / \mathrm{s}$ at 0 cells $/ \mathrm{ml}$ to $2.67 \times 10^{-11} \mathrm{~m} / \mathrm{s}$ at $2.40 \times 10^{9}$ cells $/ \mathrm{ml}$, only treatment at $2.40 \times 10^{9}$ cells $/ \mathrm{ml}$ using BSH compactive effort met the regulatory value of $1.0 \times 10^{-9}$ $\mathrm{m} / \mathrm{s}$ for this model. The Brooks-Corey [9] model recorded the least predicted unsaturated hydraulic conductivity in the range of $8.67 \times 10^{-9} \mathrm{~m} / \mathrm{s}$ at 0 cells $/ \mathrm{ml}$ to $1.56 \times 10^{-12} \mathrm{~m} / \mathrm{s}$ at $2.40 \times 10^{9}$ cells $/ \mathrm{ml}$. On the other hand, the FredlundXing [11] model predicted unsaturated hydraulic conductivity values that are between the values predicted by [9 and 10] models. Similarly, at $1500 \mathrm{kPa}$ matric suction, van Genuchten [10] model recorded higher uns aturated hydraulic conductivity values, in the range of $1.23 \times 10^{2} \mathrm{~m} / \mathrm{s}$ at 0 cells $/ \mathrm{ml}$ to $1.42 \times 10^{-11} \mathrm{~m} / \mathrm{s}$ at $2.40 \times 10^{9}$ cells $/ \mathrm{ml}$; while the Brooks-Corey [9] model recorded the least predicted unsaturated hydraulic conductivity in the range of $3.11 \times 10^{-9} \mathrm{~m} / \mathrm{s}$ at 0 cells $/ \mathrm{ml}$ to $3.27 \times 10^{-14} \mathrm{~m} / \mathrm{s}$ at $2.40 \times 10^{9}$ cells $/ \mathrm{ml}$. As previously reported, [11] model recorded values that are in between the range predicted by [9 and 10] models respectively. Os inubi et al.(2015) [31] reported similar results.

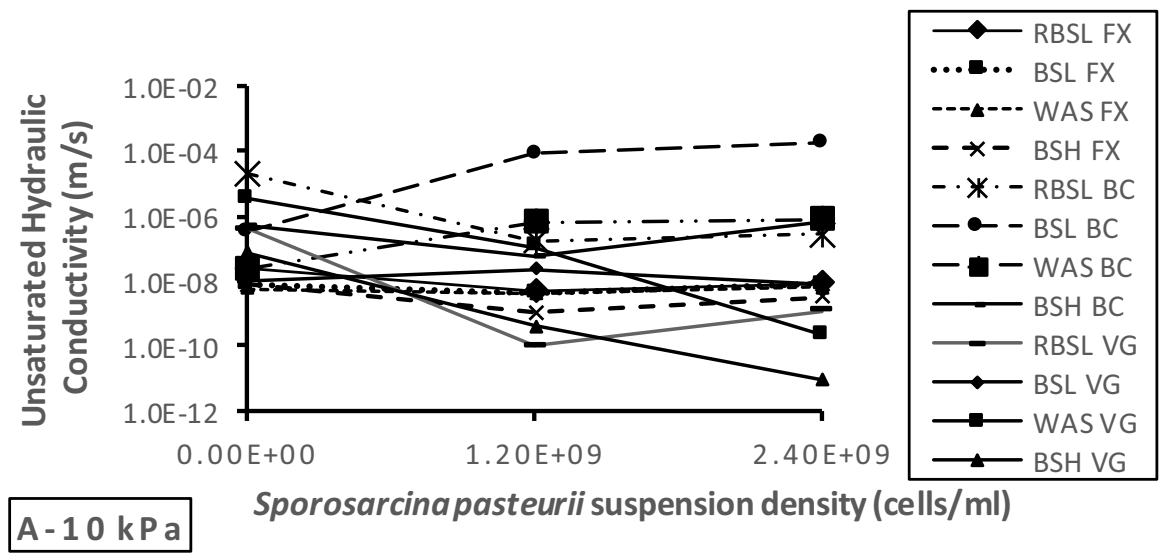




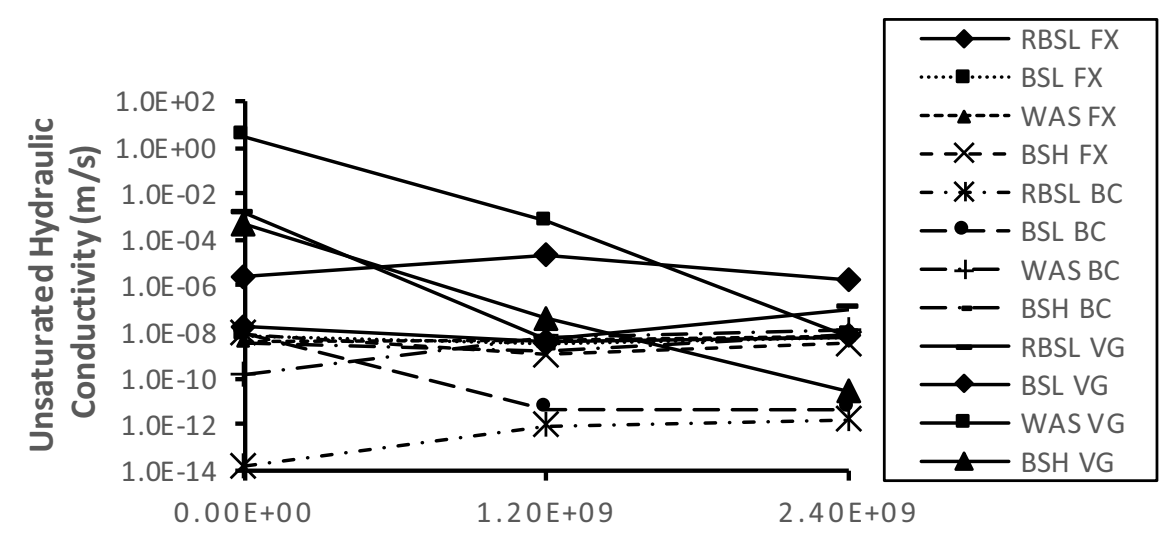

B-500 kPa Sporosarcinapasteurii suspension density (cells/ml)

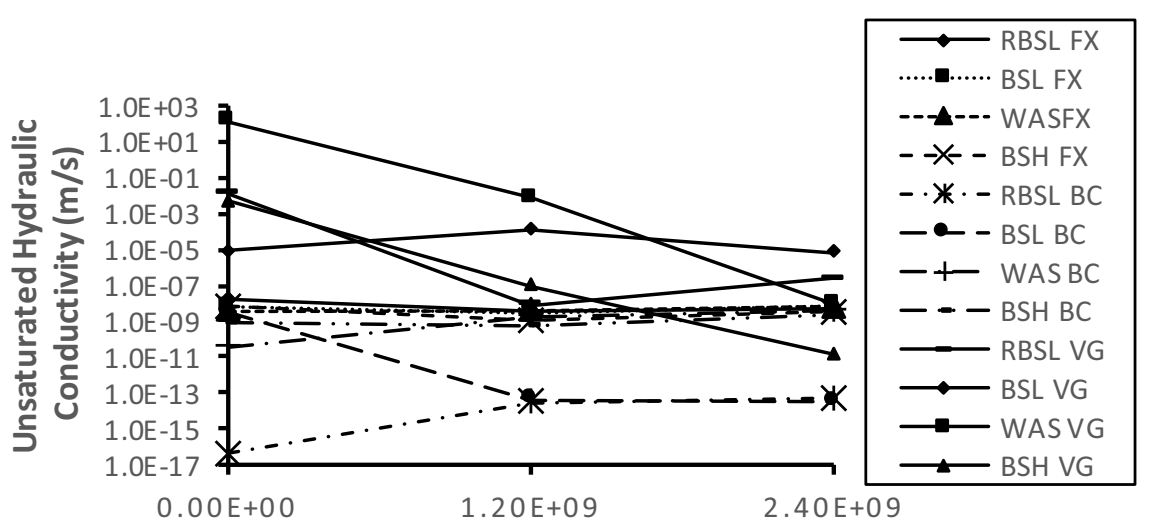

C $1500 \mathrm{kPa}$ Sporosarcinapasteurii suspension density (cells/ml)

Fig. 2 Variation of unsaturated hydraulic conductivity of lateritic soil - S. pasteurii mixture compacted at optimummo is ture content based on Brooks-Corey(BC), van Genuchten (VG), and Fredlund-Xing (FX) models for matric suctions : (A) $10 \mathrm{kPa}$ (B) $500 \mathrm{kPa}$ and (C) 1500 $\mathrm{kPa}$.

\subsubsection{Effect of compactive effort}

The changes recorded due to compactive effort on the unsaturated hydraulic conductivity predicted by BrooksCorey [9] model for varying $S$. pasteurii suspension density is presented in Fig.3a-c. The range of matric suction used in the study is between $10 \mathrm{kPa}-1500 \mathrm{kPa}$, the highest and lowest values of the predicted unsaturated hydraulic conducvity recorded within these pressure range is discussed. It was generally observed that there was a linear decrease in the unsaturated hydraulic conductivity with increase in matric suction. For the natural soil at $10 \mathrm{kPa}$ the highest hydraulic conductivity value of $2.04 \times 10^{-5} \mathrm{~m} / \mathrm{s}$ was recorded using RBSL compactive effort, while the lowest value recorded was $2.37 \times 10^{-8} \mathrm{~m} / \mathrm{s}$ using WAS compactive effort, at $1500 \mathrm{kPa}$. The highest value recorded was $3.12 \times 10^{-9} \mathrm{~m} / \mathrm{s}$ using BSL while the lowest value recorded was $4.47 \times 10^{-17} \mathrm{~m} / \mathrm{s}$ using RBSL compactive effort.
At $1500 \mathrm{kPa}$, the highest value recorded was $1.73 \times 10^{-9}$ $\mathrm{m} / \mathrm{s}$ using WAS while the lowest value recorded was $2.60 \times 10^{-14} \mathrm{~m} / \mathrm{s}$

For soil specimen treated at $10 \mathrm{kPa}$ suction, the highest hydraulic conductivity value of $1.67 \times 10^{-3} \mathrm{~m} / \mathrm{s}$ was recorded using WAS ; while the lowest value recorded was $2.40 \times 10^{-7} \mathrm{~m} / \mathrm{s}$ using RBSL compactive effort. At $1500 \mathrm{kPa}$, the highest value recorded was $7.10 \times 10^{-14} \mathrm{~m} / \mathrm{s}$ using RBSL while the lowest value recorded was 3.33 $\times 10^{-}$ ${ }^{15} \mathrm{~m} / \mathrm{s}$ using BSH compactive effort. For soil specimen treated with $1.20 \times 10^{9}$ cells $/ \mathrm{ml}$, at $10 \mathrm{kPa}$ suction; the highes thydraulic conductivity value of $7.89 \times 10^{-5} \mathrm{~m} / \mathrm{s}$ was recorded using BSL, while the lowest value recorded was $5.75 \times 10^{-8} \mathrm{~m} / \mathrm{s}$ using BSH compactive effort. At $1500 \mathrm{kPa}$ the highest value recorded was $1.71 \times 10^{-9} \mathrm{~m} / \mathrm{s}$ using WAS while the lowest value recorded was $3.05 \times 10^{-14} \mathrm{~m} / \mathrm{s}$ using RBSL compactive effort. Similarly, for soils specimen treated at $10 \mathrm{kPa}$ suction, the highest hydraulic conductivity value of $6.11 \times 10^{-4} \mathrm{~m} / \mathrm{s}$ was recorded using BSL, while the lowest value recorded was $1.66 \times 10^{-7} \mathrm{~m} / \mathrm{s}$ using RBSL compactive effort. At $1500 \mathrm{kPa}$, the highest value recorded was $4.23 \times 10^{-14} \mathrm{~m} / \mathrm{s}$ using $\mathrm{BSH}$ while the 
lowest value recorded was $7.75 \times 10^{-21} \mathrm{~m} / \mathrm{s}$ using WAS compactive effort. Furthermore, for soils specimen treated with $2.40 \times 10^{9}$ cells $/ \mathrm{ml}$, at $10 \mathrm{kPa}$ suction, the highest hydraulic conductivity value of $1.80 \times 10^{-4} \mathrm{~m} / \mathrm{s}$ was recorded using BSL, while the lowest value recorded was $2.83 \times 10^{-7} \mathrm{~m} / \mathrm{s}$ using RBSL compactive effort. At 1500 $\mathrm{kPa}$, the highest value recorded was $3.91 \times 10^{-9} \mathrm{~m} / \mathrm{s}$ using WAS while the lowes tvalue recorded was $3.27 \times 10^{-14} \mathrm{~m} / \mathrm{s}$ us ing BSL compactive effort. From the results presented, it can generally be concluded that RBSL compactive effort recorded the least predicted unsaturated hydraulic conductivity values except at WAS compactive effort which recorded the least predicted unsaturated hydraulic conductivity values. The obs erved trend could probably be due to the precipitation of calcite within the pores of specimens prepared at lower compactive effort (especially the RBSL), resulted in a lower prediction of unsaturated hydraulic conductivity values.
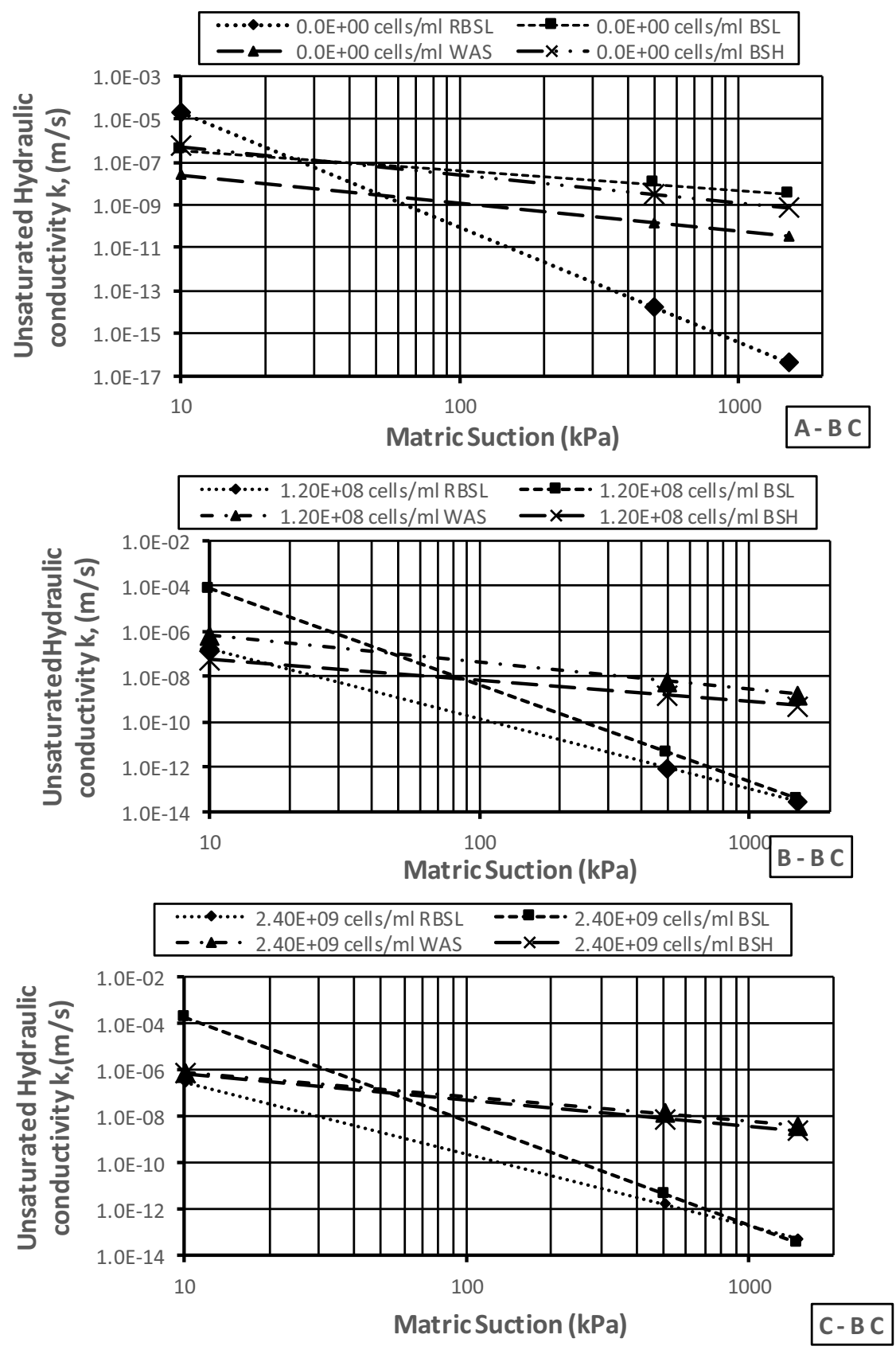

Fig.3 Variation of unsaturated hydraulic conductivity of lateritic soil prepared at optimum mois ture content with matric suction based on Brooks - Corey (BC) model for S. pasteurii suspension density:(A) 0 cells $/ \mathrm{ml}$, (B) $1.20 \times 10^{9}$ cells $/ \mathrm{ml}$ and (C) $2.40 \times 10^{9}$ cells $/ \mathrm{ml}$. 
The changes due to effect of compactive effort on the predicted unsaturated hydraulic conductivity using van Genuchten [10] model for varying $S$. pasteurii s uspension density is presented in Fig. 4a-c. In contrast to the predicted values obtained using [9] model, there was a linear increase in the unsaturated hydraulic conductivity values with increasing matric suction. As previously discussed, at $10 \mathrm{kPa}$ suction for the natural soil, the highest value was $3.52 \times 10^{-6} \mathrm{~m} / \mathrm{s}$ using WAS, while the lowest value recorded was $1.08 \times 10^{-8} \mathrm{~m} / \mathrm{s}$ using BSL compactive effort, at $1500 \mathrm{kPa}, 1.24 \times 10^{2} \mathrm{~m} / \mathrm{s}$ was recorded as the highest value using WAS and $8.21 \times 10^{-6}$ $\mathrm{m} / \mathrm{s}$ as the lowest using BSL compactive effort. At $10 \mathrm{kPa}$, the highest and lowest unsaturated hydraulic conductivity values were $3.13 \times 10^{-8} \mathrm{~m} / \mathrm{s}$ and $4.40 \times 10^{-10}$ using BSL and RBSL compactive efforts respectively, while at $1500 \mathrm{kPa}$, the highest and lowest values are $1.25 \times 10^{-4} \mathrm{~m} / \mathrm{s}$ and $7.93 \times 10^{-8} \mathrm{~m} / \mathrm{s}$ using BSL and RBSL compactive efforts separately. At $10 \mathrm{kPa}$, the highest and lowest values were $2.90 \times 10^{-8} \mathrm{~m} / \mathrm{s}$ and $3.48 \times 10^{-9} \mathrm{~m} / \mathrm{s}$, using RBSL and WAS compactive efforts respectively. At 1500
$\mathrm{kPa}$ suction, the highest and lowest values were $8.29 \times 10^{-}$ $5 \mathrm{~m} / \mathrm{s}$ and $2.23 \times 10^{-6} \mathrm{~m} / \mathrm{s}$ using RBSL and WAS compactive efforts respectively. Similar results were recorded for soil specimen treated with $1.20 \times 10^{9}$ and $2.40 \times 10^{9}$ cells $/ \mathrm{ml}$ at both 10 and $1500 \mathrm{kPa}$ matric suction. In all the various suspension densities used in the study, only treated soils at $S$. pasteurii of $1.20 \times 10^{9}$ cells $/ \mathrm{ml}$ satisfied the regulatory hydraulic conductivity requirement of $1.0 \times 10^{-9} \mathrm{~m} / \mathrm{s}$ using RBSL compactive effort at $10 \mathrm{kPa}$ matric suction and at $2.40 \times 10^{9}$ cells $/ \mathrm{ml}$ both at 10 and $1500 \mathrm{kPa}$ matric suction using $\mathrm{BSH}$ compactive effort. The prediction from this modelwould not be suitable for application since the the soil at matric suction of $10 \mathrm{kPa}$ at which the hydraulic conductivity requirements were met is still saturated as such could not give true unsaturated properties of the treated soil. From the presented results, it can be concluded that van Genuchten [10] model is not appropriate for the predictions of unsaturated hydraulic conductivity of a soil classified according to AASHTO [32], as an A-4-3 soil treated with S. pasteurii using MICP approach.
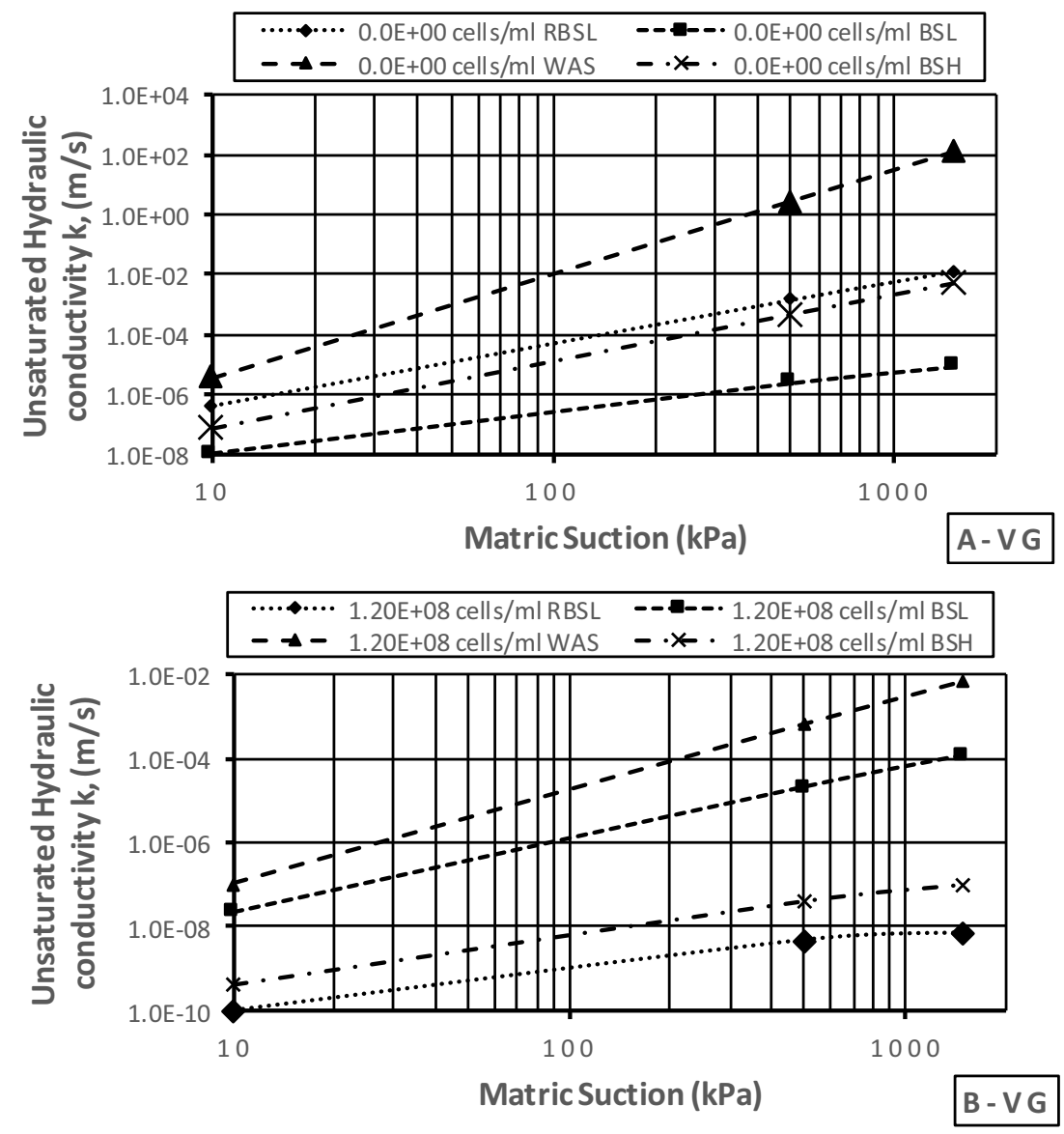


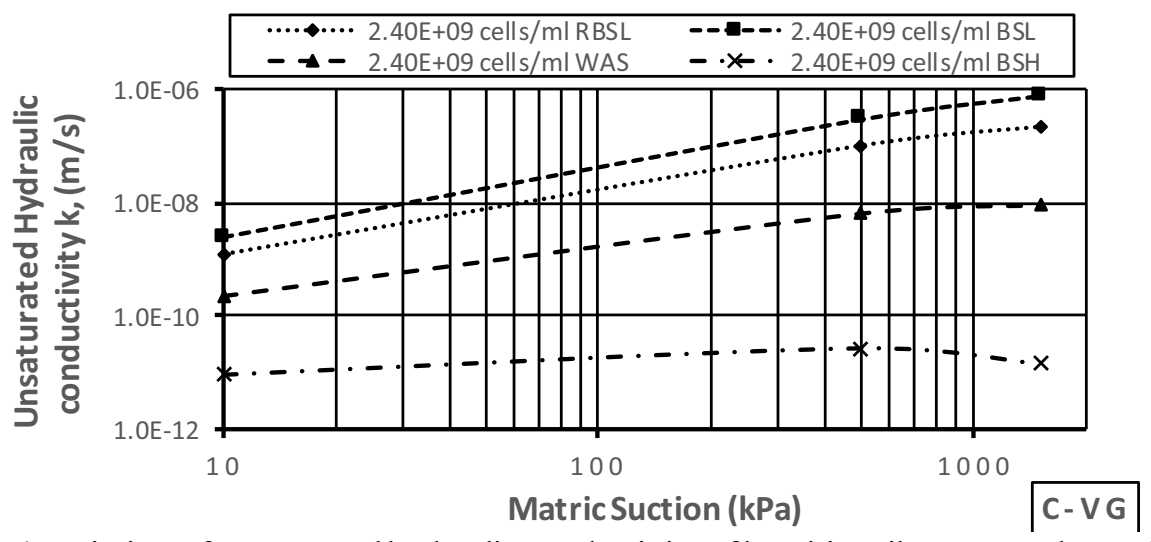

Fig.4 Variation of unsaturated hydraulic conductivity oflateritic soil compacted at optimum mo is ture content with matric suction based on van Genuchten (VG) model for $S$. pasteurii suspensiondensity: (A) 0 cells $/ \mathrm{ml}$, (B) $1.20 \times 10^{9}$ cells $/ \mathrm{ml}$ and (C) $2.40 \times 10^{9}$ cells $/ \mathrm{ml}$.

The variation in the unsaturated hydraulic conductivity predicted using Fredlund-Xing [11] model for varying $S$. pasteurii suspension density due to compactive effort is presented in Figs. 5a-c. A gradual decrease in the predicted unsaturated hydraulic conductivity values was recorded with increas ing matric suction. The values predicted using the Fredlund-Xing model are similar to those obtained using the Brooks-Corey [9] model that showed more substantial reduction with increasing matric suction. The values predicted by the two models are at variance with the values recorded for [10] model that under predicted the unsaturated hydraulic conductivity values and as well recorded an increase in the predicted unsaturated hydraulic conductivity values with increase in matric suction. Furthermore, the effect of changes in compactive effort on the predicted values was not significant for all the treated specimens except for Figs. 5b. This has not satisfied the maximum regulatory hydraulic conductivity value of
$1.0 \times 10^{-9} \mathrm{~m} / \mathrm{s}$. Comparatively, from Figs. 3a-c - 5a-c; all the treatment options used, the predicted values met the regulatory hydraulic conductivity value of $1.0 \times 10^{-9} \mathrm{~m} / \mathrm{s}$ at higher matric suction which displayed unsaturated hydraulic properties. In Figs. 4a-c out of the various $S$. pasteurii suspension densities used in the study, only soils treated with $S$. pasteurii of $1.20 \times 10^{9}$ cells $/ \mathrm{ml}$ met the regulatory hydraulic conductivity requirement of $1.0 \times 10^{-}$ $9 \mathrm{~m} / \mathrm{s}$ using RBSL compactive effort at $10 \mathrm{kPa}$ matric suction and at $2.40 \times 10^{9}$ cells $/ \mathrm{ml}$ both at 10 and $1500 \mathrm{kPa}$ matric suction using BSH compactive effort. From the results presented, the prediction model by Brooks-Corey model [9] predicted values that better represent the unsaturated hydraulic properties of the treated soil than the van Genuchten [10] model, which over predicted the uns aturated hydraulic conductivity.

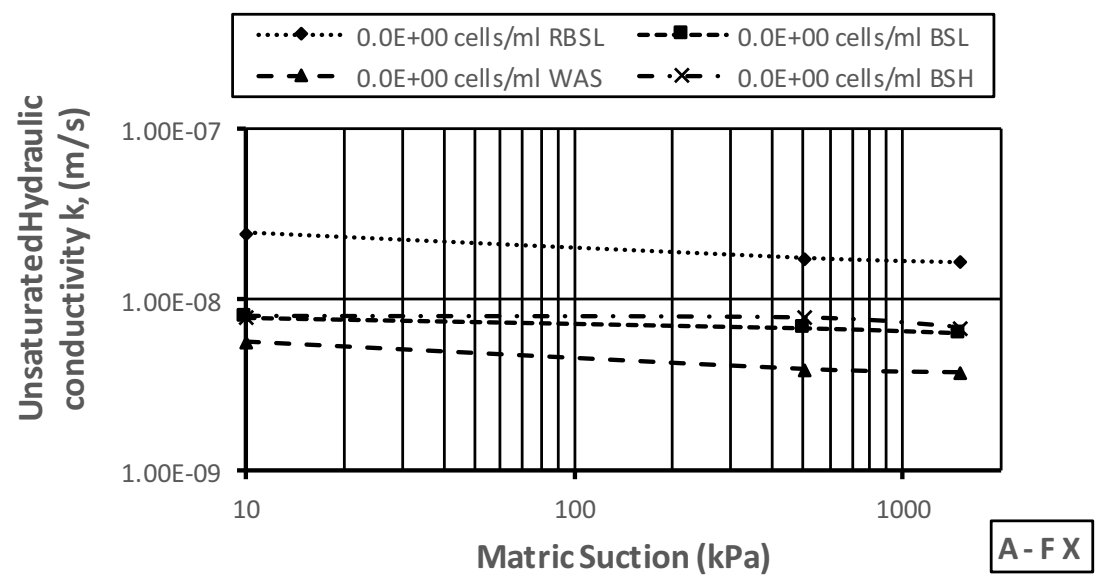



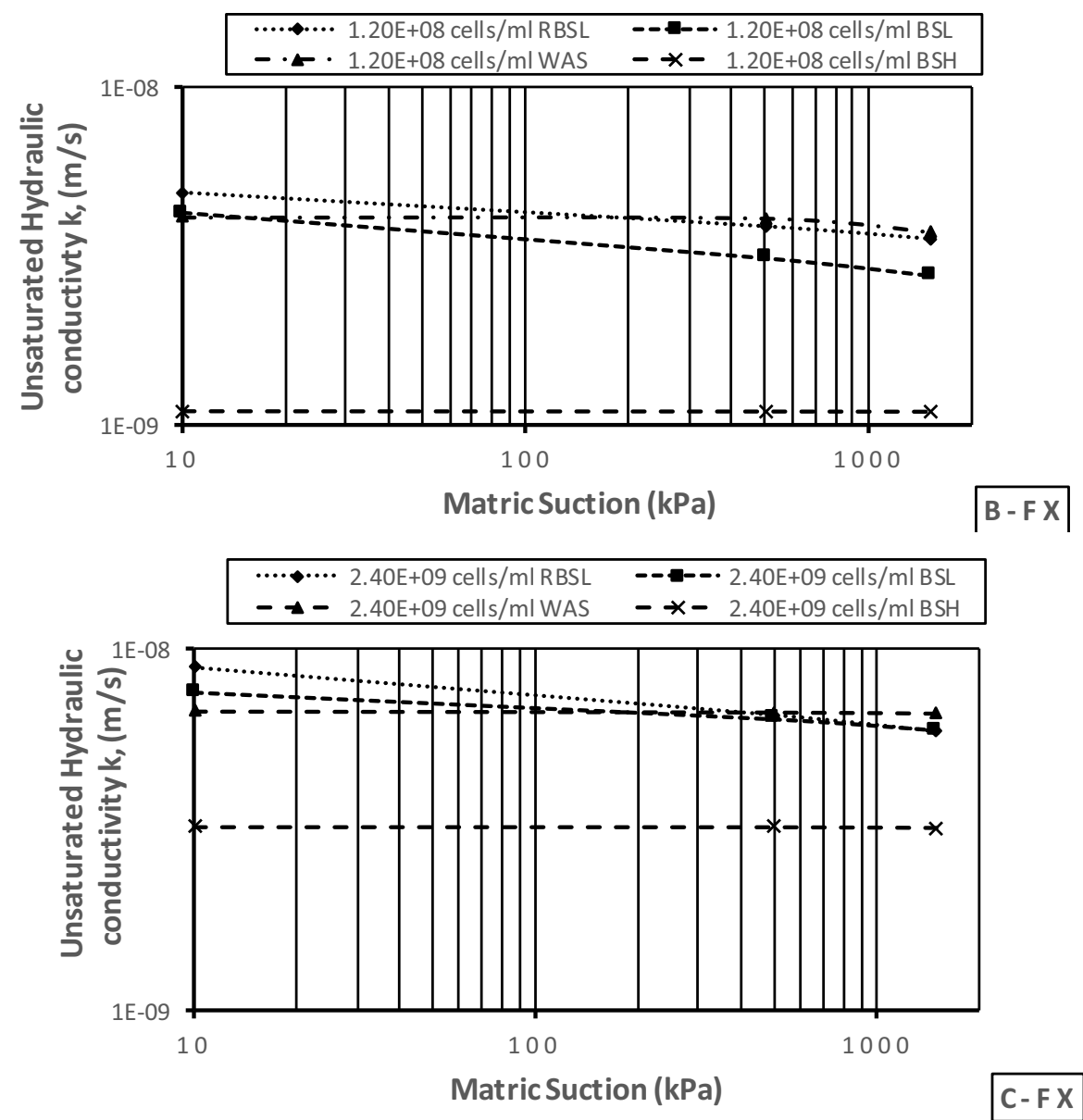

Fig.5 Variation of unsaturated hydraulic conductivity of lateritic soil prepared at optimum mo is ture content with matric suction based on Fredlund and Xing (FX) model for S. pasteurii suspension density :(A) 0 cells $/ \mathrm{ml}$ (B) $1.20 \times 10^{9}$ cells $/ \mathrm{ml}$ and (C) $2.40 \times 10^{9} \mathrm{cells} / \mathrm{ml}$.

\section{CONCLUDING REMARKS}

From the results of the study conducted on the unsaturated hydraulic conductivity of lateritic soil treated with varying $S$. pasteurii suspension density and compacted with RBSL, BSL, WAS and BSH at moulding water content from $-2 \%$ to $+2 \%$ relative to optimummoisture content, the following concluding remarks can be made: Although the other two prediction models gave good results, the Brooks-Corey model gave the best prediction of uns aturated hydraulic conductivity values which fit the requirements for waste containment facilities over the matric suction range and S. pasteurii suspension densities considered.

\section{REFERENCES}

1. D.G. Fredlund \& H. Raharjo (1993b). The roleof unsaturated soil behavior in geotechnical engieering practice. Eleventh Southeast Asia Geotechnical Engineering Conference, 4-8 May, Singapore. Pp37-50.

2. D.G. Fredlund \& H. Raharjo (1993a). Soil Mechanics for unsaturated soils. John Wiley \& ons, Inc, New York.

3. K.-B. Chin, E-C. Leong \& H. Rahardjo (2010). A simplified method to es timate the soil-water

Characteristic curve. $C$
Characteris tics curve. Can. Geotech. Jour. 47: 1382-1400 (2010) doi: 10.1139T10-033

4. H. Tao, C. Chen, P. Jiang \& L. Tang (2017). Soil water characteristic curves based on particle analysis. Procedia Engineering 174 (2017) 1289 - 1295, doi: 10.1016/j.proeng. 2017.01.273

5. K-K. Phoon, A. Santoso \& Y. Cheng (2008). Probabilis tic Analysis of Soil W ater Characteristic Curves from Sandy Clay Loam. (ASCE) GeoCongress 2008: Characterization, Monitoring, and, Modelling of Geosystems. 917-925

6. K-K. Phoon, A. Santoso \& S-T. Quek (2010). Probabilistic Analysis of Soil-Water Characteristic Curves. (ASCE) Journ. of Geotech. and Geoenviron. Engin. 136(3): 445-455. DOI: 10.1061/_ASCE_GT.19435606.0000222

7. K.R. Mahmood \& A.H. Abdul Kareem(2010). Nature of Soil-Water Characteris tics Curves (SWCC) for Soils from Anbar Governorate. Arab. Journ. ofEngin. Sci. 3(1) 62-80.

8. M. Wang, L. Kong \& M. Zang (2015). Effects of sample dimensions and shapes on measuring soil-water 
characteristic curves using pressure plate. Journ. of Rock Mechan. and Geotech. Engin. 7 (2015) 463e468. http://dx.doi.org/10.1016/j.jrmge.2015 .01.002

9. R.H. Brooks \& A.T. Corey (1964). "Hydraulic properties of porous media", Colorado State University, Hydrology Paper No.3, Fort Collins, Colorado.

10. M.T. van Genuchten (1980). A closed form equation for predicting the hydraulic conductivity of uns aturated soils'. Soil Sci. Socie. of Amer. Journ. 44, 892 -898.

11. D.G. Fredlund \& A. Xing (1994). "Equations for s oil water-characteristic curve". Can. Geotech. Journ. 31, Pp521-532.

12. K.J. Os inubi \& A.A. Amadi(2010). Variations in Soil Water Characteristic Curves of Lateritic Soil Treated with Bentonite. Experimental and Applied Modeling of Unsaturated Soils (ASCE) Geotech. Spec. Publi. No. 202. 88-95.

13. T.Y. Elkady A., Al-Mahbashi, M. Dafalla \& M. AlShamrani (2017). Effect of compaction state on the soil water characteristic curves of sand-natural expansive clay mixtures. Europ. Journ. of Environ. and Civil Engin. 21: 3, 289-302, DOI:10.1080/19648189.2015.1112844.

14. C.E., Zapata, W.N. Houston, S.L. Houston \& K.D. Walsh (2000). Soil-Water Characteristic Curve Variability. Advances in an unsaturated soils. GeoDenver 2000 (ASCE) Geotech. Spec. Public. 84-124.

15. E. Braudeau, G. Hovhannissian, A.T. Assi \& R.H. Mohtar (2014). Soil water thermodynamic to unify water retention curve by pressure plates and tensiometer. Fron. in Earth Sci. 2(30) pp 1-12. doi: 10.3389 /feart.2014. 00030

16. A. Rahimi, H. Rahardjo \& E. Leong (2015a). Effect of range of soil-water characteristic curve measurements on estimation of permeability function. Engin. Geol. 185 (2015) 96-104, http://dx. doi.org/10.1016/j.enggeo. 2014.11.017

17. N. Alsherif, A. Wayllace \& N. Lu (2015). "Measuring the Soil Water-Retention Curve Under Positive and Negative Matric Suction Regimes," Geotech. Testi. Journ. 38(4), 2015, pp. 442-451, doi:10.1520/GTJ20140258. ISSN0149-6115

18. L. Li, C. Lin \& Z. Zhang (2017). Utilization of shaleclay mixtures as a landfill liner material to retain heavy metals. Mater. and Desig. 114 (2017) 73-82. http://dx.doi. org/ $10.1016 /$ j.matdes.2016.10.046

19. S.K. Vanapalli, D.G. Fredlund, D.E. Pufahl \& A.W. Clifton (1996). Model for the prediction of shear strength with respect to s oil suction. Can. Geotec. Journ. 33: 379392
20. L. Bo \& C. Yulong (2016). Influence of Dry Density on Soil-Water Retention Curve of Uns aturated Soils and Its MechanismBased on Mercury Intrusion Porosimetry. Transac. of Tian. Univ. 2016, 22: 268-272, DOI 10.1007/s12209-016-2744-5

21. S. Nazari, M.M. Hassanlourad, E. Chavoshi \& A. Mirzaii (2018). Experimental Investigation of Unsaturated Silt-Sand Soil Permeability. Advan. in Civ. Engin.Volume 2018, Article ID 4946956, 12 pages. https://doi.org/10.1155/ 2018/4946956.

22. N. Lu (2020). Unsaturated Soil Mechanics : Fundamental Challenges, Breakthroughs and Opportunities. (ASCE) Journ. of Geotech. and Geoenv. Engin. 2020, 146(5) : 02520001-9. https://doi. org/ 10.1061/(ASCE)GT.1943-5606. 0002233

23. M. Chees brough (2006). Dis trict Laboratory Practice in TropicalCountries Part 2 Second Edition Cambridge University Press, New York

24. B.M. Mortenson, M.J.Haber, J.T. Dejong, L.F. Cas lake \& D.C. Nels on (2011). 'Effects of environmental factors on microbial-induced calcite precipitation. Appl. Microbiol., 111 (2), 338 - 349. DOI: 10.1111/j1365-2672-2011.05065x

25. K. Feng, B.M. Montoya \& T.M. Evans (2014). 'Numerical investigation of microbial induced cemented sand mechanical behaviour. Pro. Geo-Congress 2014: Technical Papers, ASCE, Geotech. Spec.

Public. 234, 1644-1653.

26. K. Rowshanbakht, M. Kamehchiyan, R.H. Sajedi \& M.R. Nikudel(2016). 'Effects of injected bacterial suspension volume and relative density on carbonate precipitation resulting from microbial treatment. Eco.Engin. 8949-55. Dx.doi.org/10.1016/ j.ecoleng.2016.01.010.

27. J.T. Dejong, M.B. Fritzges \& K. Nus s lein (2006). 'Microbial induced cementation to control sand response to undrain shear. ASCE, Journ. of Geotech. and Geoenv. Engin. 132(11), 1381 - 1392. DOI: 10.1061/ (ASCE) 1090-0241 (2006)132:11 (1381).

28. C.J. Miller, N. Vesiller, K. Yaldo \& S. Merayyan (2002). "Impact of soil type and compaction conditions on soil water characteristics". ASCE,Journ. of Geotech. and Geoenv. Engin.. 128(9) 733-742.

29. E.C. Leong \& H. Rahardjo (1997). 'Review of soil water characteristic curve equations'. ASCE, Journ. of Geotech. and Geoenv. Engin. 123(12), 1106-1117

30. A. Corey (1994). Mechanics of immiscible fluids in porous media. Water Resources Publications, Highlands Ranch, Colo. Dolinar, B. (2015) Prediction of the soil-water characteris tic curve based on the specific surface area of fine-grained soils. BullEng Geol Environ (2015) 74:697-703 DOI 10.1007/s10064-014-0664-y 
31. K.J. Osinubi \& A.O. Eberemu (2010). 'Soil water characteristic curve parameters of compacted lateritic soil treated with bagasse ash. "Geotech. Spec. Public. (GSP) ASCE. In: Experimental and Applied Modeling of Unsaturated Soils. Edited by Laureano R. Hoyos, Xiong Zhang and Anand J. Puppala, GSP 202: 79 - 87. DOI 10.1061/41103(376)11.

32. AASHTO (1986). Standard Specifications for Transport Materials and Methods of Sampling and Testing. 14th Edition, American Association of State Highway and Transport Officials (AASHTO), Washington, D.C 